Качак Т. Б.,

кандидат філологічних наук, докторант кафедри української літератури ДВНЗ «Прикарпатський національний університет імені Василя Стефаника»

\title{
ЛІТЕРАТУРА ДЛЯ ДІТЕЙ ТА ЮНАЦТВА: ПРОБЛЕМИ МЕТОДОЛОГІї ДОСЛІДЖЕННЯ
}

У статті висвітлено проблему формування в украӥнському літературознавстві методології дослідження літератури для дітей та юнаџтва. Маргарита Славова подає чотири основні підходи як напрямки теорії дитячої літератури: педагогічний, психологічний, аналіз літератури для дітей у контексті рецептивної естетики та культурології. У статті розглянуто філологічний та інші критичні підходи (наратологічний, рецептивно-естетичний, компаративний), які практикували у наукових дослідження українські літературознавиі. Детально охарактеризовано літературознавчу, дидактичну та мультидисциплінарну інтерпретаційні стратегії та ефективність їх інструментарію у дослідженні художніх текстів для дітей та юнацтва.

Ключові слова: література для дітей та юнацтва, методологія, філологічний підхід, літературознавча інтерпретачійна стратегія, мультидисииплінарна інтерпретачійна стратегія.

The article is devoted to the problem of the methodology formation of the study of literature for children and youth in the Ukrainian literary criticism. Margarita Slavova presents four main approaches to the theory of children's literature: pedagogical, psychological, literature analysis for children in the context of receptive aesthetics and cultural studies. The article deals with philological and other critical approaches (naratology, receptive-aesthetic, comparative), which Ukrainian literary scholars practiced in scientific researches. The literary, didactic and multidisciplinary interpretation strategies and the effectiveness of their tools in the study of artistic texts for children and young people are described by the author in detail.

Key words: literature for children and youth, methodology, philological approach, literary interpretation strategy, multidisciplinary interpretation strategy.

В статье освещена проблема формирования в украинском литературоведении методологии исследования литературы для детей и юномества. Маргарита Славова подает четыре основных подхода как направления теории детской литературы: педагогический, психологический, анализ литературы для детей в контексте рецептивной эстетики и культурологии. В статье рассмотрень филологический и другие критические подходы (наратологический, рецептивно-эстетический, компаративный), которые практиковали в научных исследования украинские литературоведы. Подробно охарактеризованы литературоведческая, дидактическая и мультидисциплинарная интерпретационные стратегии, эффективность их инструментария в исследовании художественных текстов для детей и юношества.

Ключевые слова: литература для детей и юночества, методология, филологический подход, литературоведческая интерпретационная стратегия, мультидисииплинарная интерпретационная стратегия.

Наукові студії, присвячені літературі для дітей і про дітей, набувають все більшого розмаху. Від спорадичних міркувань, критичних рецепцій окремих творів чи творчості письменників, дослідники прямують до теоретичних 
узагальнень, глибокого аналізу із використанням різноманітних підходів та апробацією новітніх методологій. Література для дітей стає повноцінним об’єктом дисертаційних досліджень. Очевидно, розвиткові такої тенденції сприяє низка факторів: домінування філологічного, а не педагогічного підходу до аналізу творів для дітей; стрімкий розвиток як оригінальної, так i перекладної літератури для дітей завдяки активному книговиданню та широкому спектру видавничих пропозицій на ринку дитячої літератури; посилена увага суспільства до проблем дитячого читання та розвитку i популяризації літератури для дітей; вивчення практики досліджень літератури для дітей зарубіжних науковців та екстраполяція їх досвіду у вітчизняному літературознавстві. Однак і надалі залишається актуальною проблема теорії літератури для дітей та юнацтва. Незважаючи на розвиток практичної критики, досі не розроблено i не узагальнено системи методологічних підходів i принципів аналізу цього сегмента мистецтва слова. Українська література для дітей та юнацтва - художньо-естетичне явище, котре потребує літературознавчого осмислення й аналізу, інтерпретації та фахової оцінки. На часі - виписування моделей застосування літературознавчої методології та мультидисциплінарного інструментарію для вивчення сучасної української прози для дітей та юнацтва.

В українському культурному просторі переважає розуміння літератури для дітей та юнацтва як сегмента загальної літератури. Найчастіше вона виступає об’єктом філологічних (у широкому розумінні) студій. Меншою мірою дослідники розглядають іiі крізь призму педагогічного підходу, який користувався популярністю у ХХ столітті. Спостерігається тенденція залучення до вивчення дитячої літератури новітніх продуктивних критичних інтерпретаційних підходів, які уже кілька десятиліть успішно практикують зарубіжні вчені.

Ще у 1990-х роках Маргарита Славова, теоретико-літературні роботи якої «нині вважаються початком сучасних студій у площчині теорії літератури для dimeй» [Кизилова 2013:28], констатувала в галузі студій літератури для дітей та 
юнацтва «метання та пошук методологічних опор то в педагогіці та психоаналізі, то в теорії інформації та семіотиці, то в рецеептивній естетиці та культурологї̈», зауважила що «діахронна перспектива підходів до дитячої літератури приводить до незмінного для ї̈ буття та самосвідомості відношення “дидактичне - художнє”, яке розглядає естетичну проблематику крізь педагогічний ракурс» [Славова 2002:8]. Виокремлені нею чотири основні підходи до дитячої літератури як напрямки теорії дитячої літератури розглядали Ольга Папуша, Уляна Баран (Гнідець), Богдана Салюк, Віталіна Кизилова, Світлана Бартіш - автори дисертаційних досліджень літератури для дітей та юнацтва останніх років. Мова йшла про педагогічний, психологічний підходи, аналіз літератури для дітей у контексті рецептивної естетики та культурології.

У теоретичному полі не йшлося про філологічний підхід 3 опорою на літературознавчий текстуальний аналіз творів для дітей та юнацтва, незважаючи на те, що практично його використовували найчастіше, про що свідчать монографічні дослідження, наукові статті, розвідки науковців. Маргарита Славова у докторській дисертації «Проблеми поетики белетристики для дітей» (1992) окреслила специфіку літератури для дітей, яка проявляється через ігрове i фантастичне. Літературознавець проаналізувала компоненти структури (персонаж, сюжет, композиція, оповідач та ін.) белетристичного твору для дітей i зауважила типологічну схожіть із казковою структурою. Екстраполюючи західну практику вивчення літератури для дітей, М. Славова обгрунтовує комунікативні аспекти дитячої книги, соціокультурну роль літературної казки і поглиблює теорію дитячої літератури демонстрацією методів і прийомів аналізу поетики класичних творів світової літератури. Її праця стала поштовхом для вітчизняних досліджень літератури для дітей та юнацтва у ракурсі комунікативного, наратологічного та рецептивноестетичного аспектів. Саме така перспектива розширила горизонти текстозорієнтованих історико-літературних студій дитячої літератури, які почали 3’являтися в українській академічній науці з 1970-х років. 
Текстуальний аналіз поетики художніх творів для дітей («фаховий аналіз 3 позицій художності») - незмінна складова історико-літературних студій дитячої літератури з другої половини ХХ століття і до сьогодні. Це ілюструють наукові дослідження Д. Білецького («Шляхи розвитку української радянської літератури для дітей та юнацтва (1917-1967)», 1972), Ю. Ярмиша («Українська радянська літературна казка (1917-1967)», 1974), С. Іванюка («Українська радянська проза для дітей. 1917-1941. Герой і концепція адресата», 1987), Р. Стаднійчук («Проблеми формування морального світу підлітка в сучасній радянській повісті про школу (70-80рр.)», 1990), Ірини Бойцун («Твори Є. Гуцала для дітей: проблеми художньої майстерності», 2000), Наталії Тихолоз («Жанрові модифікації казки у творчості Івана Франка», 2003), Галини Сабат («Казки Івана Франка: особливості поетики “Коли ще звірі говорили”», 2006), Ольги Будугай «Пригодницько-шкільна повість для дітей 1960-1980-х років: жанрові особливості (О. Огульчанський, Б. Комар, А. Давидов)», 2007), Оксани Гарачковської («Українська літературна казка 70-90х років XX ст.: сюжетнообразна структура, хронотоп», 2008), Наталії Резніченко («Українська проза для дітей 60-80-х років XX століття (жанрово-стильові модифікації)», 2008), Лариси Ткаченко («Виховні концепти й особливості поетики української дитячої поезії початку XX ст. (на матеріалі творчості Марійки Підгірянки, Олександра Олеся, Миколи Вороного)», 2008), Олени Чепурної («Дискурс дитини у прозі українських письменників-шістдесятників (Гр. Тютюнник, В. Близнець, Є. Гуцало)», 2008), В. Костюченка («Літературними стежками. Нарис історії української літератури для дітей», 2009), Оксани Цалапової («Міфопоетика казкового світу раннього українського модернізму (Дніпрова Чайка, Леся Українка, Олександр Олесь, Михайло Коцюбинський», 2010), Наталії Сидоренко («Жанрові модифікації і поетика української дитячої повісті 60-80 років XX століття», 2010). Не вдаємось до глибшого аналізу цих праць, оскільки він був здійснений В. Кизиловою [Кизилова 2013].

Традиційно-усталені підходи до вивчення художнього тексту як мистецького феномену й новітні досягнення у галузі теоретичного осмислення 
природи художньої творчості (історико-типологічні, рецептивні, герменевтичні стратегіï, засади структуралізму, інтертекстуальності, наратології) декларує у дослідженні «Художня специфіка української прози для дітей та юнацтва другої половини XX століття» (2013) Віталіна Кизилова [Кизилова 2013:8]. У полі зору літературознавця - жанрово-стильові тенденції літературної казки та пригодницької прози. Визначення жанрових характеристик, ідейно-естетичних й поетологічно-стильових домінант творів найрепрезентативніших письменників і виявлення певних закономірностей розвитку прози для дітей та юнацтва стало можливим завдяки дослідницькому інструментарію текстуального аналізу, який домінував у роботі. Такий інтерпретаційний формат класичний і традиційний: «передусім текст, а згодом його рефлексія 3 наступними аналітичними візіями. 3 одного боку, справді слід звернути увагу на похідні від “дорослої” літератури концеепиії дослідження тексту, адресованого дітям, з другого - важливими й вагомими є саме об'єктивні чинники, щуо зумовили статус літературознавчих статегій» [Мацевко-Бекерська 2011:19].

Нові критичні підходи до вивчення літератури для дітей відкривають ширші можливості літературознавчих студій та збагачують дослідницьку парадигму. Потенціал наратологічного підходу до вивчення літератури для дітей теоретично i практично висвітлила Ольга Папуша у дисертаційному дослідженні «Наратив дитячої літератури: специфіка художнього дискурсу» (2004). Її методика базується на теорії наративного дискурсу, семіотичних та рецептивно-зорієнтованих підходах, комунікативнах методах дослідження літератури для дітей i «дозволяє досліджувати дитячу літературу, з одного боку, як будь-який інший фіктивний дискурс, а з іншого, як специифічну форму у відноченні до різних концептів (автор, текст, читач)» [Папуша 2004].

Комплекс наратологічного, структуралістського, рецептивного методів та методів загальної теорії комунікації став методологічною основою дослідження «Специфіка комунікації в літературі для дітей та юнацтва (на матеріалі сучасної німецькомовної прози)» (2008) Уляни Гнідець (Баран) [Гнідець 2008]. 
Компаративне дослідження традиційних образів дитини-бешкетника у художніх творах для дітей і про дітей з актуалізацією типологічного підходу, культурно-історичного, порівняльного, біографічного, інтертекстуального, архетипного методів провела Богдана Салюк («Типологія традиційних образів дитини-бешкетника у художніх творах для дітей і про дітей» [Салюк 2013]).

Дитячу літературу, яка розвивається та продуктивно функціонує на кількох важливих рівнях, Лідія Мацевко-Бекерська називає складним поліінтрепретаційним феноменом. «Маємо констатаиію факту - $y$ загальнолітературному просторі існуе та його складова, що адресується категорії рещипієнтів за певними параметрами відповідності, що вирізняється очікуваними інтерпретаџійними настановами, що повинна зближуватися із канонічними наративними технологіями. Однак иілком об'єктивною $\epsilon$ теоретична поліваріантність у ияарині дитячої літератури, позаяк не тотожними є вихідні спонуки для дослідження. 3 культурологічної позииії необхідно зосередитися на своєрідності закладеності у тексті глобального світоглядного коду й способах його відчитання. 3 педагогічно-дидактичною метою варто диференціювати жанрово-вікові співвідношення. Натомість, рецептивна естетика, спираючись на психологічний аспект, акцентує увагу на дискурсі дитинства як осерді специфічної субкультури» [Мацевко-Бекерська Л 2011:19]. У літературознавчій риториці оприявнюються загальнокультурні, психологічні та інтерпретаційні категорії. Останні - через дидактичний чи своєрідно рецептивний аспект.

Множинність ракурсів, у яких можна розглядати дитячу літературу, «іншими словами - поліфонічність утворюваного довкола неї наукового та суспільного дискурсу» [Огар 2012:8] зумовлена, на думку Емілії Огар, iї поліморфною і поліфункціональною комунікативною природою. Дослідницьку перспективу теоретичного осмислення феномену дитячої книги, яка стала об'єктом іï дослідження, взаємодоповнюють дидактичний та літературознавчий підхід. У руслі літературознавчого дослідження дитяча література як частина 
літературного процесу піддається формалістичному, структурнофункціональному, семіотичному, рецептивному аналізу.

Оперуючи поняттям «текст для дітей», семантичне поле якого вміщує окрім інших явища, означувані поняттями «книга для дітей» та «література для дітей», Наталія Марченко розмежовує літературознавчий i книгознавчий науковий дискурс, накреслюючи два напрямки досліджень: загальнолітературний (ширше - загальнокультурний) та соціокультурний, міждисциплінарний [Марченко 2011]. На думку науковця, саме «книжку для дітей» як предмет наукового розгляду термінологічно та поняттєво повноцінно представлено і досліджено.

Ольга Папуша вважає, що процес вивчення явища дитячої літератури та сприйняття тексту «переважно відбувається у трьох напрямках: 1) дослідження виникнення, народження творів дитячої літератури (інтенцій на фаза); 2) вивчення процесу оформлення текстів (вербалізація, візуалізація $i$ m. п.), тобто феноменального світу дитячих книг і періодики (об'єктна фаза); 3) диференцііація книг на етапі сприйняття їх дорослими $i$ дітьми (nерцеептивна фраза)» [Папуша 2017:172]. Актуальною є потреба концептуального осмислення феномену дитячої літератури як синтезу «ycix трьох напрямків дослідження з урахуванням не лише інтегрального характеру цุього явища, а і його динамічного характеру», зважаючи на те, що у сучасному українському літературознавстві маємо ситуацію, «коли інтенційна фраза вивчається літературознавством, об'єктна фраза - книго- $i$ мистецтвознавством, перцеептивна - психолого-педагогічними науками» [Папуша 2017:173].

Значно ширша методологічна платформа зарубіжних досліджень літератури для дітей. Петер Хант (Peter Hunt), Девід Рад (David Rudd) та Карін Леснік-Обертейн (Karín Lesnik-Oberstein) з Великобританії, Ханс-Хейно Еверс (Hans-Heino Ewers) 3 Німеччини, Зохар Шавіт (Zohar Shavit) 3 Ізраїлю досліджують питання термінології, критики i теорії літератури для дітей. У своїх студіях науковці практично актуалізують методи і засоби герменевтики 
(Marah Gubar), семіотики (Zohar Shavit), психоаналітичної критики (Нamida Bosmajian, John Cech), наратологіï (Maria Nikolajeva, Barbara Wall, Anita Moss), феміністичної критики (Lissa Paul, Carina Garland), рецептивної естетики (Michael Benton), мультикультуралізму (Joh C. Stott), екокритики (Marek Oziewicz), постколоніальних студій (R. McGillis), інтертекстуальності (Christine Wilkie-Stibbs), компаративістики (Emer O’Sullivan), гендерної критики (Кarín Lesnik-Oberstein), лінгвістики (John Stephens) і стилістики (Charles Sarland), когнітивної лінгвістики (Marcello Giovanelli). Слушно зауважує Богдана Салюк: «Вітчизняне літературознавство de јиге визнає необхідність ияілісного студіювання дитячої літератури, але de facto неохоче відходить від традицій вивчення творів для дітей у рамках історії літератури, обережно використовуючи досвід зарубіжного літературознавства, який, на нашу думку, є корисним задля поступової зміни акиентів у дослідженні дитячої літератури від периферійного до изентрового» [Салюк 2013:14].

Зважаючи на специфіку об’єкта дослідження, умовно можна накреслити кілька інтерпретаційних стратегій, серед яких найбільш поширені літературознавча, дидактична, мультидисциплінарна. $\mathrm{y}$ контексті літературознавчих студій важливими й актуальними будуть рецептивний, психологічнй, культурологічний, гендерний, постколоніальний, психоаналітичнй, герменевтичний, структурно-семіотичнй, інтертекстуальний та інші критичні підходи й методи пізнання літератури.

Отже, коротко проаналізуємо специфіку й функціональність трьох найпоширеніших інтерпретаційних стратегій. Літературознавча інтерпретаційна стратегія будується на філологічних концепціях i розгортається у площині аналізу літератури для дітей та юнацтва як естетичномистецького феномена. У центрі уваги науковця - поетика тексту. У випадку, коли йдеться не про один твір і навіть не про творчість одного письменника, а про цілий пласт національної літератури, а метою роботи $є$ узагальнення письменницького досвіду та виведення тенденцій сучасної української прози для дітей та юнацтва, текстуальний аналіз поглиблюється історико- 
літературним та типологічним, підсилюється новими критичними підходами. Літературознавча інтерпретаційна стратегія покликана виявити $\mathrm{i}$ пояснити специфіку літератури для дітей на рівні поетики текстів, вказати на іï художню своєрідність, тенденції. У фокусі дослідницького інструментарію критичних підходів, актуалізованих у ii руслі, об’єкт дослідження постає у різних контекстах.

У процесі вивчення літератури для дітей та юнацтва присутня орієнтація письменника на читача певного віку, від чого й залежить закладений у текст зміст, форма його представлення. Автор і читач - дві ключові фігури, які перебувають поза текстом, але саме завдяки їхній комунікації відбувається його реалізація. Рецептивна інтерпретаційна модель розгортається у площині комунікативного процесу (адресант - текст - адресат) і пов'язана із явищами кодування та декодування, психологічним критерієм розуміння специфіки дитячої літератури. Рецептивно-естетичний підхід, як і психологічний, культурологічний, гендерний, постколоніальний, психоаналітичний, герменевтичний, структуралістський, інтертекстуальний, біографічний та інші критичні підходи до аналізу літератури розглядають художній текст через призму різних контекстів. Літературу для дітей та юнацтва неможливо вивчити поза цими контекстами, бо іï специфіка закладена в орієнтації на адресата, який $\epsilon$ поза текстом (рецептивно-естетичний підхід), психологічних особливостях творення та відчитування текстуальних смислів (психоаналітичний підхід), прописуванні фемінних та маскулінних концептів у текст (гендерний, феміністичний підходи, маскулінні студії), суспільних уявленнях про дитинство і субкультуру дитинства (культурологічний) тощо.

Дидактична інтерпретаційна стратегія опирається на функціональний аспект літератури для дітей, зокрема навчальну та виховну спрямованість текстів. При цьому досліджуваний сегмент літератури розглядається не як художньо-естетичне самоцінне явище, а як засіб навчання та виховання. У центрі уваги дослідника - дидактичність, повчальність тексту, роль книжки в 
ідеологічному вихованні юного покоління, iі функціональні можливості у розвитку та становленні особистості дитини, ефективності освітнього процесу.

Дидактичнй підхід до вивчення літератури для дітей лежить поза площиною філологічного дослідження обраного предмета, оскільки функціональний аспект не $є$ тим інструментом, який дозволяє розкрити художню специфіку текстів. «Бачити сутність літератури в ї̈ функиіі (або функціях) означає звужувати ї̈, по-перше, до ролі «голої техніки», натомість не враховувати ї̈ антропологічні, екзистенційні та психо-суспільні аспекти» [Касперський 2006:17]. Маргарита Славова зауважує, що педагогічний підхід до дитячої літератури є характерним не тільки для початкового етапу осмислення необхідності спеціальної літератури для дітей, а й для більш пізнього часу. Його застосування щодо об'єкта дослідження «негативно впливає як на розвиток дитячої літератури, так $i$ на формування уявлень про межі дитячого читання» [Славова 2002:9]. Виховні наміри дорослих (видавництв, критиків, учителів, батьків) та їх рекомендації щодо читання одних і відкидання інших книг провокують виникнення «педагогічної цеензури дитячого читання». Таке явище мало місце у радянські часи, коли створювались спеціальні інституції, які здійснювали ідеологічний контроль за дитячою літературою. У тогочасних дослідженнях цей пласт літератури завжди відносили до виховання, a «претензія дидактичного критерію» часто перетворювалась на диктат.

«Сьогодні так званий «літературний дидактизм» вважається пройденим етапом у розвитку дитячої літератури. Але дидактичний критерій, знаходячи підставу у віковій дистаниії між автором та реципієнтом, до цзього часу претендує на роль одного із основоположних критерї̈в изєё літератури» [Славова 2002:9]. Позицію автора - дорослого, який може претендувати на роль учителя, наставника, передають змістові категорії, відображає наративний план тексту. Так, діалогічну напругу між двома нерівними суб'єктивностями: дорослим автором і дитиною-читачем Марія Ніколаєва вважає ознакою, яка вказує на іманентну естетику літератури для дітей [Nikolajeva 2004:175]. I ця 
особливість твору, призначеного для дітей, стає предметом наратологічного та рецептивно-естетичного аналізу.

Мультидисциплінарна інтерпретаційна стратегія передбачає взаємодію різних галузей наукового знання у вивченні літератури для дітей та юнацтва як багатогранного соціокультурного феномену. Пізнавальною основою та інструментарієм дослідження виступають знання і методологія різних дисциплін: літературознавства, педагогіки, психології (вікової психологї, гендерної психологіï), філософіï, культурології, антропології, соціології. Відбувається інтеграція інформації, фактів, концепцій, теорій та методів 3 метою всебічного вивчення i пояснення тенденцій розвитку, специфіки літератури для дітей та юнацтва. Мультидисциплінарна інтерпретаційна стратегія стає можливою завдяки накопиченню результатів міждисциплінарних досліджень. Ще у 80-х роках Зохар Шавіт у своєму дослідженні «Роetics of Children's Literature» (Shavit Z. Poetics of Children's Literature. - Athens, 1986. Р. ХI) застосувала інтегративний підхід до дитячої літератури, розширивши перспективи іï вивчення.

Всі підходи та методики одночасно застосувати неможливо, але вони є важливими у контексті дослідження певної тематичної чи жанрової групи творів, творчості певних письменників, аналізу та узагальнень щодо характеру розвитку літератури певної доби тощо. Неможливо також зупинитися на одному підході чи методі, бо «пізнання якогось явищза за допомогою методу $\epsilon$ завжди пізнанням його фрагменту замість інщого, щзо його міг би видобути проігнорований метод. Інакше кажучи, метод щуось відкриває, але й щзось затуляє. Натомість методу «на все» не існує» [Касперський 2006:36]. Ефективність методу часткова i локальна i тільки методологічний плюралізм здатний забезпечити універсальність. «У сфері літературознавства він особливо бажаний. Багатоманіття $і$ різнорідність методів уможливлюють багатоманіття $i$ різнорідність пізнавальних «прочитань» літератури, розиирюють і поглиблюють розуміння текстів» [Касперський 2006:36]. 
Отже, окреслені інтерпретаційні стратегії не однаковою мірою використовуються у практиці вітчизняних досліджень. Дидактична інтерпретаційна стратегія була особливо актуальна у XX столітті, коли література для дітей виступала засобом ідеологічного виховання. Мультидисциплінарна інтерпретаційна стратегія - досвід зарубіжних науковців i перспектива майбутніх вітчизняних досліджень літератури для дітей та юнацтва, яка буде можлива за умови активізації наукового інтересу до об'єкта вивчення фахівців з різних галузей знань. У межах філологічного наукового дискурсу найпоширенішою i найефективнішою $\epsilon$ літературознавча інтерпретаційна стратегія, в якій методи текстуального аналізу доповнюють способи і прийоми вивчення об’єкта (його структурних, функціональних особливостей, властивостей, а також взаємодій 3 навколишнім світом), задекларовані критичні підходи. Практика методологічного плюралізму та поєднання різних критичних підходів у межах дослідження літератури для дітей є особливо важливою, коли мова йде про висвітлення тенденцій: закономірностей i напрямку розвитку, узагальнення художньо-естетичних особливостей, соціокультурної специфіки об’єкта вивчення.

\section{БІБЛІОГРАФІЯ}

Гнідець 2008 - Гнідець У. С. Специфіка комунікації в літературі для дітей та юнацтва (на матеріалі сучасної німецькомовної прози) : автореф. дис. канд. філол. наук : 10.01.04 / Уляна Святославівна Гнідець. - Сімферополь, 2008. $20 \mathrm{c}$.

Касперський 2006 - Касперський Е. Література. Теорія. Методологія / Едвард Касперський // Література. Теорія. Методологія: Пер. 3 польської С. Яковенка / Упор. і наук. ред. Д. Уліцької. - К. : Вид. дім «Києво-Могилянська академія», 2006. - С. 2-37.

Кизилова 2013 - Кизилова В. В. Художня специфіка української прози для дітей та юнацтва другої половини XX століття : монографія / В. В. Кизилова. Луганськ : Вид-во ДЗ «ЛНУ імені Тараса Шевченка», 2013. - 400 с. 
Марченко 2011 - Марченко Н. «Текст для дітей» як форма самоусвідомлення та трансформації суспільства / Н. Марченко // Наукові праці Нац. бібліотеки України ім. В. І. Вернадського. - 2011. - Вип. 31. - С. 509-519.

Мацевко-Бекерська 2011 - Мацевко-Бекерська Л. Дитяча література як форма діалогу культур : герменевтичний аспект / Л. Мацевко-Бекерська // Література. Діти. Час : Вісник Центру дослідження літератури для дітей та юнацтва. Вип. 1. - Тернопіль : Навчальна книга - Богдан, 2011. - С. 18-24.

Огар 2012 - Огар Емілія. Дитяча книга в українському соціумі (досвід перехідної доби) : монографія / Емілія Огар. - Львів : Світ, 2012. - 320 с.

Папуша 2017 - Папуша Ольга. Дитяча література як предмет дослідження / Ольга Папуша // «I все життя - подвижництво у рідному слові...». Статті, дослідження, спогади про професора Любов Миколаӥвну Кіліченко. - Івано-Франківськ : Місто-НВ, 2017. - 444 с. - С. 169-175.

Папуша 2004 - Папуша Ольга Миколаївна. Наратив дитячої літератури : специфіка художнього дискурсу [Текст] : автореф. дис ... канд. філол. наук : 10.01.06 / Папуша Ольга Миколаївна; Тернопільський держ. педагогічний ун-т ім. Володимира Гнатюка. - Т., 2004. - 19 с.

Салюк 2013 - Салюк Б. А. Perpetuum mobile дитячої літератури: типологія традиційних образів дитини-бешкетника : Монографія / Богдана Салюк.Донецьк: ЛАНДОН-ХХІ, 2013. - 216 с.

Славова 2002 - Славова М. Т. Попелюшка літератури. Теоретичні аспекти літератури для дітей / М. Т. Славова. - Видавничо-поліграфічний центр «Київський університет». - К., 2002. - 81 с.

Nikolajeva 2004 - Nikolajeva Maria. Narrative theory and children literature / Maria Nikolajeva // International Companion Encyclopedia of Children's Literature. Second Edition, Volume 1 Edited by Peter Hunt. London and New York. Routledge, 2004. - p. $166-178$. C. 175 